\title{
PROBLEMAS ACtUALES DE LA CONTRATACION LOCAL
}

\author{
por \\ Vicente Boix Reig
}

SUMARIO: I. INTRODUCCION.-II. SOBRE LA REVISION DE PRECIOS EN LA CONTRATACION LOCAL.-III. SOBRE LOS INTERESES DE DEMORA.-IV. SORE LOS PROCEDIMIENTOS DE CONTROL INTERNO DE LAS CONTRATACIONES.V. SOBRE LA REALIZACION DE OBRAS POR ADMINISTRACION.-VI. UNA REFERENCIA AL SINGULAR SISTEMA DE CONTRATA DE LOS LLAMADOS "ARRENDAMIENTOS DE SERVICIOS».

\section{INTRODUCCION}

De un tiempo a esta parte se ha ampliado sensiblemente la actividad de gestión de servicios públicos por parte de las Corporaciones locales. No es extraño a este fenómeno la definición autonómica con la que la Constitución vigente ha venido a situar a Ayuntamientos y Diputaciones provinciales en una clara mayoría de edad política y administrativa.

El fenómeno va a llevar de suyo, entre otras consecuencias, la necesidad de prestar especial atención a uno de los principales instrumentos jurídicos que utilizan los Entes locales para llevar a la práctica sus intervenciones en la vida social: la contratación.

La contratación local se regula por el régimen aplicable a la contratación estatal: hay una remisión completa en el artículo 5.C) de la Ley Reguladora de las Bases del Régimen Local, completada 
en el artículo 112.2 del Texto Refundido (Real Decreto Legislativo $781 / 1986$, de 18 de abril), que ha modificado sensiblemente la normativa anterior, en la que existía una reglamentación propia, y sólo supletoriamente o por analogía era de obligado cumplimiento la Ley de Contratos del Estado y el arco de normas que la desarrolla.

Pero la aplicación al ámbito local de la normativa estatal lleva aparejada algunas matizaciones que parece de interés analizar.

La naturaleza de la contratación administrativa, ya superada la clásica polémica sobre los aspectos privados y públicos que pudiera haber en los convenios suscritos por una Administración, se sustenta sobre dos principios jurídicos que conviven en un permanente y tenso maridaje:

El principio de la soberanía de la voluntad, auténtica lex inter partes, consagrado en el artículo 1.255 del Código Civil y recogido en el artículo $3 .^{\circ}$ de la Ley de Contratos del Estado, y el principio del «a riesgo y ventura» que asienta la voluntad administrativa en el respeto a determinados presupuestos y contenidos del contrato, que se califican de interés público.

La bóveda de la institución contractual no será otra que la resultante de la confrontación de los dos indicados principios aparentemente antagónicos. La Administración diseñará sus preofertas contractuales, desde el respeto a determinadas exigencias, que se denominan requisitos formales, y a partir de las mismas establecerá las condiciones que considere más convenientes.

El desarrollo contractual requerirá el respeto a las originarias garantías formales. Lo que introduce una peligrosa rigidez y aun dificultad para el buen desarrollo del contrato: el principio de «a riesgo y ventura" puede provocar el colapso de la institución contractual en las relaciones pactadas con relativa duración en el tiempo. Surgirán entonces cuestiones de una cierta relevancia económica, como la revisión de precios o los intereses, y se plantearán también cuestiones de nuevo diseño técnico, como son la realización de obras por administración, como alternativa a la gestión por contratistas interpuestos.

Sobre estas y otras materias el ordenamiento jurídico va a salir al paso. Pero la regulación resultante suscita el planteamiento de algunas observaciones. 


\section{SOBRE LA REVISION DE PRECIOS EN LA CONTRATACION LOCAL}

En esta materia las referencias del Derecho local vienen de antiguo (1). Y en todo caso es de directa aplicación la legislación especial que sobre la materia se ha venido dictando para la Administración del Estado (2).

La revisión de precios puede configurarse como una técnica jurídico-financiera, que introduce cierta elasticidad en el cumplimiento contractual desde el principio del equilibrio financiero, que intenta conservar en los contratos de cierta duración un justo balance de prestaciones y contraprestaciones. Técnica tanto más necesaria en épocas recesionistas en las que la inflación puede desajustar las reglas establecidas para un contrato determinado en un momento originario.

Lo explica el Dictamen del Consejo de Estado de 13 de julio de 1971: «La contratación administrativa del momento actual debe responder a la teoría del equivalente económico, y a este principio responde la revisión de precios.»

Podemos resumirla en un apretado compendio de las reglas que la regulan:

a) Que la inclusión de cláusulas de revisión de precios en los contratos administrativos es potestativa. Artículo $1 .^{\circ}$ del Decretoley $2 / 1964$ y artículo $10^{\circ}$ del Decreto 461/1971. «Dicha revisión no se presupone, ni surge ex lege; muy al contrario, es una posibilidad jurídica que surge necesariamente ex contractu mediante su expresa inclusión en los pliegos", dice el Dictamen del Consejo de Estado precitado. Abunda en ello el artículo 82.9 del Reglamento General de Contratación del Estado.

b) Consiguientemente, la inclusión de tal cláusula no es norma de Derecho necesario, conforme señala la Sentencia del TS de 6 de

(1) La Disposición adicional segunda del Reglamento de Contratación de las Corporaciones locales, de 9 de enero de 1953, realizaba una expresa remisión. Igualmente, el artículo 109, 1, del Real Decreto Legislativo 3046/1977, de 6 de octubre.

(2) Desde los artículos 12 de la Ley de Contratación del Estado, y 30 y 82, 9, de su Reglamento, se ha dictado una legislación especial sobre revisión de precios, que fundamentalmente está constituida por el Decreto-ley 2/1964, de 4 de febrero, y por los Decretos 3650/1970, de 19 de diciembre, y 461/1971, de 11 de marzo. Con una referencia al ámbito local en el Decreto $1757 / 1974$, de 31 de mayo, al que precedió la Sentencia del TS de 19 de diciembre de 1973, declarando aplicable a las Corporaciones locales las normas del Decreto-ley de 4 de febrero de 1964. 
diciembre de 1976. Y debe venir acompañada de las determinaciones necesarias para la aplicación de los coeficientes de revisión, que en todo caso no podrán exceder de los techos normativos (art. $3 .^{\circ}$ del Decreto-ley 2/1964).

c) Tiene especial interés en la materia la pormenorizada Sentencia del TS de 23 de noviembre de 1977, que ya entonces definió los contenidos para la aplicación de esta técnica, de incipiente valoración en las Administraciones locales.

d) Conviene en todo caso especificar que, conforme establece el artículo 6..$^{\circ}$ del Decreto 1005/1974, de 4 de abril, sobre los contratos de asistencia, y el artículo 4. $.^{\circ}, 10$, del Real Decreto 1465/1985, de 17 de julio, sobre ejecución de trabajos específicos y concretos no habituales, está prohibida en los mismos la inclusión de cláusulas de revisión de precios.

Podemos alcanzar una conclusión de trabajos: la revisión de precios es potestativa y sólo es recogible en los procesos de contratación de obra pública y de suministro público.

La consecuencia parece obvia: el margen legal para la flexibilidad de las contraprestaciones contractuales es corto.

Ante el rigor formalista se ha abierto un nuevo principio con el que se intenta apuntalar el equilibrio financiero. Es el denominado principio de la compensación equitativa.

Se puede rastrear en la Sentencia del TS de 20 de marzo de 1972, en donde, frente a la obligada aplicación del rebus sic standibus, que llevaba al "a riesgo y ventura", el artículo 30 del Reglamento de Contratación del Estado permitía valorar la existencia de eventos ajenos a la voluntad del contratista, que causados por la Administración provocaban alteraciones económicas extraordinarias y anómalas, imprevistas y profundas, de tal manera que llevar entonces con rigidez el estricto cumplimiento contractual derivaría en un enriquecimiento injusto por parte de la Administración.

Hay aquí una modernización de la clásica doctrina del factum principis (3), a virtud de la cual la Administración debe indemnizar a su contratista cuando por causa de disposiciones generales administrativas se alteren las condiciones económicas de los contratos pendientes. En tal sentido, las Sentencias del TS de 11 de diciembre de 1973, 27 de abril de 1974 y 21 de junio de 1976.

(3) El Dictamen 3725 del Consejo de Estado, de 3 de noviembre de 1948, define con exactitud los requisitos que debe reunir el factum principis. 
En los momentos presentes, en que el intervencionismo administrativo provoca automáticos incrementos en costos, por ejemplo salariales o de determinados productos sometidos a regímenes de control de precios o de contingentación en la oferta, la aplicación del principio de la compensación equitativa puede llevar a erosionar el mismo sustento del principio de «a riesgo y ventura». De tal manera que, al no precisarse la concurrencia de las condiciones que se han dejado señaladas para la aplicación de la técnica de la revisión de precios, esto es, su expresa consideración en el contrato y la expresa determinación de los criterios para aplicar el coeficiente de revisión, se puede llegar a un desorden financiero en las Corporaciones locales.

No es ajeno a este peligro el legislador, que mediante Reales Decretos 1782/1983, de 15 de junio, y 1130/1984, de 11 de agosto, suspendió durante los ejercicios económicos correspondientes las pautas aplicativas de revisión que se habían actualizado en el Real Decreto 1193/1982, de 30 de abril. Pero nuevamente puesto en vigor tal mecanismo por el Real Decreto $1881 / 1984$, de 30 de agosto, ha sido desarrollado por la Orden ministerial de 5 de diciembre de 1984 ( $B O E$ del 21 de diciembre), que establece una regulación aplicativa del mecanismo de la compensación equitativa.

A la vista de esta moderna corriente es conveniente una regulación específica en los pliegos de contratación de_aquellos supuestos en los que, no estando expresada la aplicación de la técnica de la revisión de precios, se admitirá la aplicación de la compensación equitativa, pero sólo en los supuestos específicos que al efecto se detallen en el propio pliego de condiciones.

\section{SOBRE LOS INTERESES DE DEMORA}

Una retención de pagos por parte de la Administración - causados por falta de liquidez, tras la que suele encontrarse a su vez los impagos de contribuciones especiales en período voluntario (4), o la falta de previsión financiera para costos adicionales derivados de la ejecución de mayor número de unidades de obra, o de la aplica-

(4) La materia de las contribuciones especiales adolece de excesivos vaivenes legislativos: el Real Decreto Legislativo 3250/1976, de 30 de diciembre; la Ley 40/1981, de 28 de octubre; para terminar con el Real Decreto Legislativo 781/1986, de 18 de abril, y en especial sus artículos 219 y 221 . Se trata de una exacción sustentada en dos actos administrativos: el de imposición y el de aplicación. 
ción de revisiones de precios- lleva frecuentemente al contratista a realizar operaciones de autofinanciación que representan costos, generalmente de alguna dureza, con las secuelas de deterioro en la calidad de las prestaciones, e incluso llegando al bloqueo económico de los contratistas que, en ocasiones, ha llevado a la ruina a más de una empresa. Estamos ante la problemática de los intereses de demora en la contratación administrativa.

La normativa (5) regula, en primer lugar, el sometimiento al pacto contractual. El problema, por supuesto, se plantea allí donde el contrato no ha previsto sobre la cuestión, o bien absolutamente nada, o bien el procedimiento de su puesta en funcionamiento, mediante la necesidad de interpellatio; o en cuanto al período de tiempos a partir del cual deben ponerse en marcha los mecanismos para su devengo, o directamente el propio devengo.

Alguna corriente interpretativa abre nuevos campos de incertidumbre. Así, la Sentencia de la AT de Valencia de 2 de julio de 1984: "No precisándose interpellatio a la Administración, dado que se conceden estos intereses en vía de daños y perjuicios por el grave retraso de la Administración en el cumplimiento de las obligaciones, totalmente injustificado.»

La falta de soporte financiero, que previsiblemente se deriva de la interpretación antiformalista que precede, puede situar la ejecución de la previsible sentencia condenatoria en las traumáticas vías del artículo 106 de la Ley reguladora de la Jurisdicción ContenciosoAdministrativa.

Parece conveniente reafirmar la necesidad de la interpellatio, así como que ésta plantee específicamente tiempos y cuantías, y convierta la obligación administrativa en líquida -certus an y certus quando-. Exigiendo a la Administración presupuestaria local a establecer las preferencias oportunas en la habilitación de créditos. Y por parte del contratista, le obligará a pautar sus prestaciones conforme a las previsiones contractuales, impidiéndole introducirse en un proceloso mundo de ambigüedades en la obra pública, detrás del cual se pueda incluso estar buscando una residual cuenta de pérdidas para la aplicación del hecho consumado.

En tanto en cuanto no se produzca una normativa más compulsiva sobre el particular, se precisa que esta cuestión quede sufi-

(5) Artículos 47 de la Ley de Contratos del Estado y 144 de su Reglamento. 
cientemente definida en el correspondiente pliego de condiciones de la contrata.

\section{SOBRE LOS PROCEDIMIENTOS DE CONTROL INTERNO DE LAS CONTRATACIONES}

Los acotamientos legales sobre cuantías, sistemas de selección de contratistas y fórmulas de gestión directa, también han sufrido una desproporcionada alteración en el tiempo (6). Apuntándose en todo caso a través del proceso un fortalecimiento de las siguientes reglas:

a) Que las contrataciones por más de un año precisan la formalización de los correspondientes compromisos de gasto para los presupuestos sucesivos: artículo 449 del Real Decreto Legislativo 781/1986, de 18 de abril, y artículo 21, 2, de la Ley de Contratos del Estado. Debiéndose documentar en todo caso el soporte financiero, bajo vicio de nulidad de actuaciones: artículos 41, c), y 82, 3 , del Reglamento de Contratación del Estado. Tras lo cual debe contraerse el gasto: artículos 16 y 17 del mismo Reglamento de Contratos del Estado.

b) Que la actividad a contratar precisa estar debidamente especificada: artículo 56 y siguientes del Reglamento de Contratación del Estado. Precisándose autorización administrativa previa para

(6) El Real Decreto Legislativo 3046/1977, de 6 de octubre, estableció para la contratación directa, en su artículo 117, 1, 4, el límite en cinco millones de pesetas de obra o en dos años para contratos de asistencias o servicios. Tales valores se mantienen en el Real Decreto 1201/1978, de 2 de junio, completándose la condición económica lineal con la porcentual de no sobrepasar el 5 por 100 del presupuesto ordinario. La Orden de 12 de noviembre de 1981, desde su soporte en la Ley presupuestaria, autorizó contrataciones directas para obras de inversión hasta 50 millones de pesetas, sin sobrepasar el 10 por 100 del presupuesto de inversión. Porcentaje que en todo caso se rebaja en el artículo 88 de la Ley $7 / 1985$, de 2 de abril, al 5 por 100 . Y cuya cuantía límite queda igualmente rebajada a 25 millones de pesetas (sin distinguir entre obras de inversión y obras de mantenimiento) en el nuevo artículo 37, 4, de la Ley de Contratos del Estado, en la redacción dada al mínimo por el Real Decreto Legislativo 931/1986, de 2 de mayo, por el que se modifica la Ley de Contratos del Estado, para adaptarla a las directivas de la Comunidad Económica Europea. Esta rebaja es en todo caso discutible en lo que hace referencia a obras de inversión, a la vista del artículo 67 de la Ley 21/1986, de 23 de diciembre.

Las técnicas de selección se rigen por la normativa estatal. A tal efecto, el artículo 119 del Real Decreto Legislativo 781/1986, de 18 de abril, ha suprimido el concurso-subasta por aplicación de la normativa de la CEE, en concordancia con el nuevo artículo 28 de la Ley de Contratos del Estado. 
cualquier fraccionamiento de obra: artículos 125 del Real Decreto Legislativo 781/1986 y 59 del Reglamento de Contratación del Estado.

c) Que los artículos $5 .^{\circ}$ y siguientes del Real Decreto-ley 24/1982, de 29 de diciembre, introducen sustanciales novedades en materia de cuantías y de agilización del procedimiento contractual, que quedan definitivamente perfiladas y determinadas en el Real Decreto Legislativo 931/1986, de 2 de mayo.

d) Que es requisito indispensable para acceder a la contratación pública hallarse al corriente de las obligaciones tributarias, tal y como regula el Real Decreto 1462/1985, de 3 de julio (7).

\section{SOBRE LA REALIZACION DE OBRAS POR ADMINISTRACION}

Del actual sistema destacamos:

a) Que la realización de obras por adminisración se autoriza en los artículos 121 del Real Decreto Legislativo 781/1986, de 18 de abril; 60 de la Ley de Contratos del Estado, y 187 y siguientes de su Reglamento (8).

b) Que si el Ente local dispone de servicios técnicos propios suficientes debe utilizar este sistema como normal, antes de acudir a las técnicas selectivas de contratistas externos (arts. 60, 1, de la Ley de Contratación del Estado y 187, 1, de su Reglamento).

c). Que en este sistema la responsabilidad de la obra recae íntegramente sobre la propia Administración, aun en el supuesto de que se utilicen contratistas «colaboradores» [art. 191, B), del Reglamento de Contratación del Estado].

Las posibilidades de engarzar la obra por administración, con la subcontratación mediante mecanismos de selección de contratistas

(7) a) Estar dado de alta en licencia fiscal. b) Haber presentado las declaraciones o documentos de ingreso del IRPF, del Impuesto sobre Sociedades, de los pagos a cuenta o fraccionados o de las retenciones a cuenta de ambos y de los Impuestos sobre el Tráfico de Empresas y sobre el Lujo (hoy sustituidos ambos por el IVA). c) Haber presentado la relación anual de ingresos y pagos a que se refiere el Real Decreto 1913/1978, de 8 de julio (Real Decreto 1462/1985, de 3 de julio; BOE número 204 , de 26 de agosto de 1985).

(8) Difícilmente acoplable en el Reglamento de 9 de enero de 1953, constituyó en el ámbito local una novedad su regulación en el artículo 118 del Real Decreto Legislativo 3046/1977, de 6 de octubre. 
colaboradores para partes separadas, y aun la posibilidad de aplicar en estas actuaciones los mecanismos de incentivación del mercado de trabajos (9), convierten en notablemente sugestiva esta vía de gestión directa para la ejecución de obras públicas por los Entes locales.

La normativa en todo caso es especialmente rigurosa en el establecimiento de controles a la gestión administrativa, que llega incluso a la designación de un técnico supervisor diferente al técnico director, para aquellas promociones de especial costo.

El carácter novedoso de la figura, cuyos precedentes en la Administración local sólo son rastreables en el Real Decreto Legislativo 3046/1977, de 6 de octubre, está precisado de una más consistente regulación reglamentaria, para:

a) Establecer la figura del "programa» suscrito por el técnico que gestione la promoción, y en donde se especifiquen los diferentes bloques de obra pública, así como el mecanismo interno de gestión de cada uno de ellos. A fin de que la Corporación pueda adoptar acuerdo global sobre fraccionamientos, financiación, pliegos para "contratos de colaboración», dirección técnica, etc.

b) Definir las obligaciones fiscales que se van a derivar de la indicada promoción, especificando las repercusiones del IVA (10) y analizando valores de especial contundencia, como son los que diferencian el presupuesto de ejecución material del presupuesto de ejecución por contrata, que tienen una clara regulación en el artículo 68 del Reglamento de Contratación del Estado y que se corresponde con esa expresión genérica que engloba lo que se llama

(9) Interesa una valoración de un itinerario de estimulación administrativa jalonado por las Resoluciones de la Dirección General del Instituto Nacional de Empleo de 19 de agosto de 1982 y 8 de febrero de 1984, por la Orden del Ministerio de Trabajo de 21 de febrero de 1985, y, en fin, por los Reales Decretos 1495/1982, de 25 de junio, actualizado por el 1809/1986, de 28 de junio.

(10) Conviene ahora referirse al artículo 25 del Reglamento del IVA (Real Decreto $2028 / 1985$, de 30 de octubre), que con motivo de las contrataciones de las Administraciones públicas dispone literalmente: "... se entenderá siempre que los sujetos pasivos del Impuesto, al formular sus propuestas económicas, aunque sean verbales, han incluido dentro de las mismas el Impuesto sobre el Valor Añadido, que no obstante deberá ser repercutido como partida independiente, cuando así proceda, en los documentos que se presentan para el cobro, sin que el importe global contratado experimente incremento como consecuencia de la consignación del tributo repercutido.

Los correspondientes pliegos de condiciones particulares contendrán la prevención expresa de que, a todos los efectos, se entenderá que las ofertas de los empresarios comprenden no sólo el precio de la contrata, sino también el importe del Impuesto". 
beneficio industrial: gastos generales, financieros y fiscales, entre el 16 y el 20 por 100 del presupuesto de ejecución material, en el que se subsume lo que se puede considerar la renta del capital, y hasta un 6 por 100 en concepto de beneficio industrial, que obviamente debe reconducirse a los valores establecidos para lo que puede entenderse como renta del trabajo.

c) Concretar los seguimientos de la obra, desde el punto de vista técnico, así como las aprobaciones por parte de la Corporación de las diferentes certificaciones parciales, que deben de mantenerse para el correcto seguimiento y documentación de la obra.

Cuestiones que abren su horizonte reglamentario a las diferentes Comunidades Autónomas, conforme a sus competencias estatutarias.

\section{UNA REFERENCIA AL SINGULAR SISTEMA DE CONTRATA DE LOS LLAMADOS «ARRENDAMIENTOS DE SERVICIOS»}

Son las contrataciones para desarrollar «trabajos específicos y concretos no habituales de carácter excepcional», reguladas para la Administración local en el Real Decreto 2357/1985, de 20 de noviem. bre, que a su vez se remite a las reglas del Real Decreto 1465/1985, de 17 de julio.

Es ésta una materia en la que se están produciendo no pocas corruptelas por el abuso en la utilización de la figura mediante su aplicación a relaciones jurídicas para la contratación de personal, sorteando las prohibiciones establecidas por la Ley 30/1984, de 2 de agosto. 


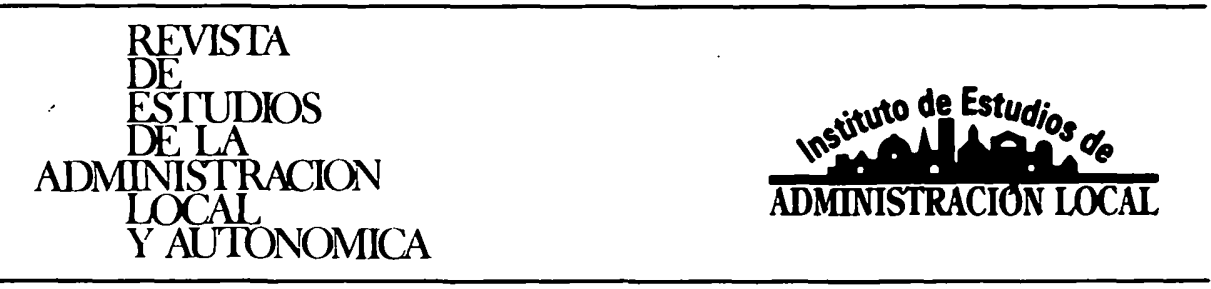

III. JURISPRUDENCIA 
REALA-1987, núm. 233. BOIX REIG, VICENTE. PROBLEMAS ACTUALES DE LA CONTRATACION LOCAL.

REALA-1987, núm. 233. BOIX REIG, VICENTE. PROBLẸMAS ACTUALES DE LA CONTRATACION LOCAL. 


\section{COMENTARIO MONOGRAFICO}

I. PARA LIQUIDAR LA TASA MUNICIPAL POR LA APERTURA DE UNA AGENCIA O SUCURSAL BANCARIA NO PUEDE TOMARSE COMO BASE DE TRIBUTACION EL TOTAL CAPITAL SOCIAL DEL BANCO A QUE AQUELLA PERTENECE

Las exacciones de derecho público con que hoy cuentan los Ayuntamientos se encuadran fundamentalmente en tres conceptos: los Impuestos, las Contribuciones Especiales y las Tasas. Estas exacciones se establecen por Ley, y los Ayuntamientos pueden dictar normas que, dentro del ámbito legal, regulen cada una de las exacciones, aprobando al efecto las Ordenanzas Fiscales correspondientes que, en todo caso, deberán contener los siguientes particulares:

a) La determinación del hecho imponible, del sujeto pasivo y de las exenciones, reducciones y demás beneficios legalmente aplicables.

b) Las bases, los tipos de gravamen aplicables o las cuotas exigibles, así como los demás elementos determinantes de la cuantía de la deuda tributaria.

c) Lo plazos y forma de declaración e ingresos.

d) El régimen de infracciones y sanciones.

e) Las fechas de su aprobación y del comienzo de su vigencia.

f) Las demás particularidades que determinen las leyes y demás disposiciones dictadas para su ejecución y las que la Entidad local estime convenientes.

En el nuevo Texto refundido de las disposiciones legales vigentes en materia de Régimen local, aprobado por Real Decreto legislativo de 18 de abril de 1986, se dedica el Título VIII a las Haciendas Locales, comprendiendo los artículos 178 a 461, inclusive. 
En el artículo 199 se dispone que los Ayuntamientos podrán establecer tasas:

a) Por la utilización privativa o por el aprovechamiento especial de bienes o instalaciones de uso público municipal.

b) Por la prestación de servicios o la realización de activịdades de la competencia municipal que beneficien especialmente a personas determinadas o, aunque no las beneficien, les afecten de modo particular simpre que, en este último caso, la actividad municipal haya sido motivada por dichas personas directa o indirectamente.

Por su parte, el artículo 212 dice que se entenderán comprendidas en el apartado $b$ ) del artículo 199 los servicios y actividades que va recogiendo en 27 apartados, diciendo en el 28: "cualesquiera otros servicios 0 actividades, siempre que se den las circunstancias previstas en el artículo $199, b$ )». Y entre los varios conceptos que incluye dicho artículo está la «licencia de apertura de establecimientos", que es la que ha dado lugar a la Sentencia del Tribunal Supremo (Sala 4. ${ }^{\text {a) }}$ del 30 de abril de 1986 (Aranzadi 4382) y de la que ahora nos ocupamos.

Los antecedentes del caso aquí resuelto por el TS son los siguientes, sintéticamente enunciados:

1. El Banco Hispano Americano solicitó del Ayuntamiento de Bilbao licencia para abrir una sucursal o agencia local en la calle de Huertas de la Villa de aquella localidad, calle situada en una zona no muy comercial.

2. El Ayuntamiento le concedió la licencia de apertura solicitada, liquidándole la tasa correspondiente, que ascendió a la cantidad de 4.935 .315 pesetas.

3. El Banco interpuso reclamación ante el Tribunal Económico-Administrativo Foral de Vizcaya, que estimó la reclamación, anulando la liquidación y ordenando al Ayuntamiento girase otra nueva sobre bases distintas.

4. El Ayuntamiento formuló recurso contencioso-administrativo ante la Sala de la Audiencia Territorial de Bilbao, la cual declaró que el fallo del Tribunal Económico-Administrativo, ahora recurrido, estaba ajustado a derecho.

5. Apelada esta Sentencia ante el Tribunal Supremo éste la confirma, aceptando los Considerandos de aquélla. 
El Ayuntamiento de Bilbao se atuvo a lo establecido en la Ordenanza fiscal aprobada al efecto y llevó a cabo la liquidación tomando como base tributaria el total del capital desembolsado y las reservas de la Empresa, Banco Hispano-Americano, que alcanza la cifra de 55.852.731.500 pesetas, con lo que el importe de la Tasa alcanza la cantidad de casi cinco millones de pesetas, estimando el Tribunal que, tomar como base de tributación el capital total del Banco cuando lo que trata de abrir es un sucursal en una calle de cuarta categoría, conduce a extremos desmesurados, ilógicos y manifiestamente injustos; y por ello estima que la base de tributación ha de estar en la parte de dicho capital que exprese la capacidad de expansión consumida por la sucursal que se trata de abrir, de conformidad con la normativa reguladora de la apertura de sucursales y agencias bancarias (D. 2245/1974 y OO. ministeriales de 20 de septiembre de 1974 y 3 de mayo de 1976), siendo así que, a tenor de la certificación expedida por la Oficina de Regulación Bancaria del Banco de España, la agencia urbana objeto de apertura y exacción consume una capacidad de expansión del Banco Hispano-Americano de 375.000 .000 de pesetas.

La Audiencia Territorial, al asumir como propia la resolución del Tribunal Económico-Administrativo, dice que tal decisión se halla conforme con la doctrina jurisprudencial establecida por el Tribunal Supremo en sus Sentencias de 10 de marzo de 1969 (Ar. 1261), 27 de mayo de 1972 (Ar. 2519), 30 de abril de 1977 (Ar. 1786), 3 de octubre de 1977 (Ar. 3694), 26 de diciembre de 1978 (Ar. 4217) y 14 de diciembre de 1979 (Ar. 4369), pues de esta jurisprudencia se extrae la siguiente doctrina:

a) Que en materia de derechos o tasas por licencia de apertura de establecimientos deben ser ponderadas las circunstancias concurrentes, para evitar que las liquidaciones que se giren por estos conceptos conduzcan a resultados desproporcionados, indicándose como medida conveniente para evitar posibles abusos el establecimiento de coeficientes correctores que permitan llegar a una consecuencia justa y razonable, en función de la naturaleza misma de la tasa y de las circunstancias que deben ser conjugadas, como la sede o ubicación del establecimiento cuya apertura se solicita.

b) Que, a la hora de fijar la base tributaria de la tasa, prescindiendo del debatido tema de si el importe ha de limitarse al coste del servicio o puede exceder de él, razones evidentes derivadas de 
los principios del Derecho tributario y de la propia naturaleza de las tasas, hecho que debe sentarse como premisa indiscutible que el Municipio que impone la exacción no podrá someter a tributación más capital social que el asignado al establecimiento que se instale en su término municipal, y

c) Que, a falta de índices correctores para la determinación de la base de la tasa, procede acudir a los criterios derivados de las normas de expansión bancaria (D. 2245/1974 y OOMM. de 20 de mayo de 1974 y 3 de mayo de 1976 y disposiciones complementarias) como medio más adecuado para llegar a una solución justa y razonable.

El Tribunal Supremo, en los Considerandos de la Sentencia, dice que se desvirtuaría la naturaleza de la tasa si se fijase la base imponible atendiendo solamente a la capacidad económica del obligado al pago, y sin tener en cuenta el coste del servicio prestado, debiendo existir una proporcionalidad entre ambos conceptos.

Para mejor conocer los matices del pensamiento del Tribunal Supremo sobre el particular, se transcriben a continuación (in partibus) los Considerandos de la Sentencia del Supremo Tribunal. $\mathrm{Al}$ efecto dice:

La tesis de la Sentencia apelada mantiene «doctrina acorde con el artículo 26, a) de la Ley General Tributaria (R. 1963, 2490 y N. Dicc. 15243) por el que se define el concepto de Tasa como contraprestación por la utilización del dominio público, la prestación de un Servicio Público, o la realización de un servicio que se refiere o afecte o beneficie de un modo particular al sujeto pasivo; desvirtuándose la naturaleza del derecho o tasa imponible cuando se fija la base imponible atendiendo solamente a la presunta capacidad económica del obligado al pago y beneficiario del servicio público, sin perjuicio de tener que atender a esa capacidad, al aprobar las tarifas, cuando la naturaleza de la tasa lo permita, artículo II del Decreto de 30 de diciembre de 1976, aunque no exclusivamente, teniendo en cuenta que por el artículo 21 del mismo Decreto, el importe total de las tasas por la realización de una actividad o prestación de un servicio no podrá exceder en su conjunto del coste real y previsible del servicio o actividad; de lo que se infiere la exigencia de una proporcionalidad entre el servicio y la tasa imponible y su debida corrección por el factor económico que dimana de la capacidad de quien tiene que satisfacerla; proporción no respetada por la Ordenanza Fiscal del Ayuntamiento de Bilbao que determina como base imponible el capital social de la Entidad que pida y se le otorgue licencia para la apertura de una sucursal, cuyá actividad queda circunscrita dentro de los límites del término municipal, con- 
cesión de licencia que no puede gravarse atendiendo a la capacidad económica del sujeto pasivo exclusivamente; ni, en el supuesto concreto de una Sociedad mercantil cuya actividad se produce también en términos municipales distintos de aquél en que se ha prestado el servicio sometido al tributo de la tasa, el factor relativo a la capacidad económica del obligado al pago no es el representado por el total de su capital social, por no ser éste indicativo de la misma en el Municipio en que realiza su actividad.

Lo alegado por la recurrente respecto a la potestad de los Ayuntamientos de ordenar sus tributos con las correspondientes Ordenanzas, artículo 717 de la Ley de Régimen Local, potestad que acorde con la autonomia municipal proclamado en nuestra Constitución, artículo 140 de esta Norma Fundamental del Estado, debe ejercerse respetando la originaria del Estado, para establecer, mediante Ley, los tributos, artículo 133 de la Constitución ( $R$. 1978, 2836), a la que se acomoda el Decreto mentado de 30 de diciembre de 1976 y la Ley General Tributaria; cuya normativa, en relación con los Derechos y Tasas, se infringe por la Ordenanza Fiscal número 5 del Ayuntamiento de Bilbao, al determinar la base imponible, aplicable para la apertura de las sucursales de una Entidad mercantil, en función de la capacidad económica de la Sociedad y fijar ésta por el total de su capital social indicativo de las actividades que desarrolla aquélla en el territorio del Municipio y fuera de él, y ajena, por tanto, a la que representa el factor económico sometido a la competencia del Ayuntamiento; llevando la aplicación de esa Ordenanza a la desnaturalización del concepto de las Tasas por prestación de un servicio municipal que se convierte en un tributo imponible sin conexión alguna con el servicio prestado».

\section{ES COMPETENCIA DE LA DIPUTACION PROVINCIAL RESPECTIVA APROBAR INICIALMENTE LA MODIFICACION DE UN PLAN DE ORDENACION URBANA QUE AFECTE A VARIOS MUNICIPIOS}

En la Sentencia del Tribunal Supremo de 8 de mayo de 1986 (Ar. 4392), se abordan varios problemas relacionados con la Ley del Suelo y Ordenación Urbana de 9 de abril de 1976, y su Reglamento de Planeamiento Urbanístico de 23 de junio de 1978, al tenerse que llevar a cabo una modificación del Plan Comarcal de Plencia-Munguía, de la Provincia de Vizcaya, a consecuencia de la construcción de una central nuclear por la Compañía Iberduero en la Cala de Basordas, del Municipio de Lemóniz.

El TS, después de recoger con gran detalle los antecedentes fác- 
ticos del caso sometido a su resolución, analiza cada una de las alegaciones del Ayuntamiento demandante, y que desestima por las razones que al efecto expone. Veamos:

1) La modificación y la revisión de un Plan de Urbanismo son conceptos distintos: la revisión comporta, como ya dejó establecido la Sentencia de 3 de mayo de 1985, la adopción de nuevos criterios en relación con la estructura general y orgánica del territorio o de la clasificación del suelo, como consecuencia de la elección de un modelo territorial distinto, o por la aparición de circunstancias que incidan sustancialmente sobre la ordenación, quedando los demás supuestos que no tengan esa transcendencia como simples modificaciones, aun cuando las alteraciones pudieran llevar consigo cambios aislados en la clasificación o calificación del suelo; y en aplicación de estos principios hay que sostener que los cambios aislados que constituyen el objeto del expediente aprobado encajan nítidamente en el concepto de la «modificación»y, por el contrario, excluyen la "revisión" de todo el Plan Comarcal de Plencia-Mungía, pues ni se adoptan nuevos criterios en relación con la estructura general y orgánica de todo el territorio abarcado por dicho Plan Comarcal, ni respecto a la clasificación del suelo del mismo como consecuencia de la elección de distinto modelo territorial, ni la construcción de esta central, en parte sobre terrenos ganados al mar y en zona marítimo-terrestre y marítima del lugar llamado Cala de Basordas, incide sustancialmente sobre la Ordenación General del Plan.

2) La modificación de un Plan puede ser formulada por particulares, pues si, como establece el artículo 52 de la Ley de Suelo, las personas privadas pueden formar toda clase de planes, pueden, por tanto, instar y formular toda clase de modificaciones de los mismos, con arreglo a lo establecido en el artículo 49 de la mencionada Ley.

3) Para la modificación del Plan era competente la Diputación Provincial, que fue la que efectivamente lo tramitó. $\dot{Y}$ al negar esta facultad se olvida lo dispuesto en el artículo 54, 2, de la vigente Ley del Suelo al decir que si los Planes afectasen a varios Municipios se presentarán en la Diputación Provincial y seguirán el procedimiento a que se refiere el número 1 del propio artículo 54 , que remite a la Sección cuarta, dentro de la que están los artículos 39 al 51. Y el artículo 40 dispone con toda claridad que la aprobación 
inicial y provisional compete al Ayuntamiente cuando se refieran a un único Municipio, y a la Diputación Provincial correspondiente cuando se extiendan a más de un término municipal. Y siendo éste el caso, no hay duda de la competencia de la Diputación Foral para la aprobación inicial y provisional de la modificación tramitada.

4) El quorum especial que exige el artículo 50 a los Ayuntamientos que hayan propuesto y aprobado inicialmente la modificación en la zonificación o uso urbanístico de las zonas verdes o espacios libres, y que supone una mayor garantía para el mantenimiento de las zonas verdes, no es de aplicación cuando el proyecto de modificación no se tramita por el Ayuntamiento sino por la Diputación en aquellos casos en que compete a la misma por tratarse de proyectos que afectan a dos o más Municipios. Estas garantías están pensadas para evitar abusos en las modificaciones o revisiones de los Planes en menoscabo de las zonificaciones establecidas para zonas verdes o espacios libres en los Planes a revisar; y abtracción hecha de que en el presente caso la zona verde inicial no se suprime sino que simplemente se traslada y aun se amplía apreciablemente, lo cierto es que tampoco se incumplió el precepto del referido artículo 50 del Texto refundido de la Ley del Suelo en cuanto al quorum reforzado que a la sazón se exigía con arreglo al artículo 303 tantas veces aludido; pues el expresado artículo 50 de la Ley del Suelo, al referirse a "acuerdos» de la Corporación local interesada, se está refiriendo inequívocamente a los acuerdos de aprobación inicial y provisional del Plan que debían ser adoptados con el quorum reforzado expresado, pero tratándose en este caso de un Plan Comarcal que afectaba a varios Municipios y en el que los acuerdos de aprobación inicial y provisional no debían ser adoptados por los Ayuntamientos respectivos sino por la Diputación Foral, es evidente que los «acuerdos» que debían ir reforzados con el repetido quorum no eran los de los Ayuntamientos sino los de la Diputación que era la Corporación local interesada que tenía a su cargo la adopción de tales «acuerdos", por lo que no se infringió el mencionado quorum por el hecho, que en las actuaciones tampoco consta, de que presuntamente, el Ayuntamiento de Lemóniz no hubiese aprobado la modificación con el quorum del repetido artículo 303 si en todo caso la intervención de la aludida Corporación no tenía lugar por la vía de los «acuerdos» del artículo 50 del Texto refundido sino por la de la audiencia a las Corporaciones locales 
afectadas del último inciso del artículo 41.1 de la misma Ley del Suelo al tratarse de la modificación de un Plan Comarcal no redactada por los citados Ayuntamientos de Lemóniz y Munguía.

Estas son las tesis mantenidas por el TS en su Sentencia respecto de diversos preceptos de la Ley del Suelo. Aún hay otros puntos de menor interés en dicha sentencia de los que no se trata por no hacer desmedido este comentario. 


\section{RESEÑA DE SENTENCIAS}

SUMARIO: I. ALCALDES: MOCION DE CENSURA SOLICITADA POR LOS CONCEJALES.-II. CONCEJALES: 1. CESE. 2. IMcompatibilidades. 3. Posible destitución del Alcalde.-III. CONTRATACION ADMINISTRATIVA.-IV. FARMACIAS: CONCESION DE LICENCIAS.-V. HACIENDAS LOCALES: 1. IMPUESTO MUNICIPAL SOBRE PUBLICIDAD. 2. IMPUESTO DE RADICACIÓN.VI. HUELGAS: SERVICIOS MINIMOS.-VII. POLICIA MUNICIPAL: 1, 2, 3. LICENCIA DE OBRAS. 4, 5. RUINA.-VIII. PROCEDIMIENTO ADMINISTRATIVO: NOTIFICACIONES.-IX. RLSPONSABILIDAD DE LA ADMINISTRACION.-X. SERVICIOS PUBLICOS.-XI. URBANISMO: 1. COMPETENCIAS DE LOS Delegados Provinciales. 2. Construcción en suelo urbanizable. 3. Estudios de Detalle. 4. Derribo de obras. 5. Suelo urbano Y No URBANIZABle. 6. Solar.

\section{ALCALDES. MOCION DE CENSURA SOLICITADA POR LOS CONCEJALES}

No puede un Alcalde dejar hasta las próximas elecciones municipales la convocatoria del Pleno municipal para tratar de la moción de censura y cese, en su caso, formulada por el quorum legal de Concejales. (Sentencia de 19 de julio de 1986, Ar. 4444.)

\section{CONCEJALES}

1. Cese de los mismos: competencia de la Corporación Municipal

El cese de un Concejal por causa de ificompatibilidad fuera del proceso electoral es competencia del Pleno de la Corporación-Sentencias de 2 de marzo de 1982 (R. 1658) y 16 de diciembre de 1983 (R. 6798)- y no de la Junta Elec- 
toral de Zong que se limita a facilitar el nombre del que corresponda sustituirle, por ser el siguiente en la lista, y extenderle la correspondiente credencial, acto de trámite no recurrible. (Sentencia de 5 de mayo de 1986, Ar. 4384.)

\section{Es incompatible el CARgo de CONCEJAL CON El FUncionario DE UNA Fundación PÚblica del MISMO AyunTamiento}

Se trata en el caso actual de médico que prestaba servicios como tal en una Fundación hospitalaria creada por el Ayuntamiento y gestionada por órgano dependiente del mismo. Se dice en la Sentencia lo siguiente:

Las Fundaciones, por el hecho de su constitución, adquieren la personalidad propia que se alega, $y$, en tal sentido, por regla general, el personal dependiente de ellas no puede entenderse que depende de quien la Fundación instituye, pero esta conclusión, en casos como el enjuiciado en que el objeto de la misma es la realización de un servicio público, no puede ser aplicada fuera del supuesto de que el mismo se preste, en régimen de gestión indirecta, por un tercero -ya sea éste una persona física o jurídica pero con personalidad propia preexistente al encomendársele la gestión-, mediante alguno de los procedimientos de concesión, arrendamiento o concierto contemplados por el artículo 113 del Reglamento de Servicios de las Corporacio nes Locales, pero no, precisamente, cuando el servicio no deja de prestarse por gestión directa de la Corporación, aunque, al efecto, se cree una Fundación pública del que sigue propiamente municipalizado, aunque adoptando una de las modalidades previstas para esta gestión directa por el 67 del propio Reglamento, por más que materialmente la efectúe el elemento personal que constituye el Patronato creado a tal fin, no exento, por ello, de la fiscalización y tutela del Ayuntamiento que lo crea, lo que, en cualquier caso, no supone que ello engendre otra personalidad distinta que la del propio servicio, habida cuenta de que la misma se atribuye a éste y no a un ente distinto del Ayuntamiento por el artículo 85 del Texto reglamentario deviniendo así el servicio simplemente "personalizado" según el 86 , con un patrimonio especial afecto a los fines específicos de la institución creada pero cuya titularidad dominical el propio Ayuntamiento conserva, que se rige por un Estatuto aprobado por la Corporación misma y con una dirección y administración a la que ésta no es ajena.

Sentado lo que precede fácil es advertir que la relación de empleo existente entre el actor y el Hospital de la Merced genera la incompatibilidad prevista en el artículo 9.1.b) de la Ley de 17 de julio de 1978, dada la contraposición de intereses y el área de coincidencia que puede existir entre el desempeño de cargo de Concejal y la relación de empleo mencionado, ya que la incompatibilidad de que se trata dado el tenor del precepto ha de enten. derse que abarca tanto a los funcionarios de carrera como a los de empleo e igualmente cualquier contrato en régimen administrativo o laboral, a los que 
debe referirse, en concreto el término aempleados» que la Ley suma al de afuncionarios», en consideración a todo lo cual procede desestimar el recurso, declarando que el acuerdo recurrido es conforme al Ordenamiento Jurídico. (Sentencia de 2 de abril de 1986, Ar. 4217.)

\section{Petición de que se convoque Pleno Municipal PARA TRATAR DE La GESTIÓN DEL AlCalde Y SU POSIBLE DESTITUCIÓN}

En la sentencia recurrida se ha seguido una doctrina jurisprudencial favorable a la celebración de Plenos Extraordinarios en los que, realizada la petición de los mismos en determinadas condiciones para ser debatida - solicitud suscrita al menos por un número determinado de los Concejales-, se trata la moción de censura y subsiguiente destitución del Alcalde, ya que, pretender como hace el hoy apelante, que las proposiciones de moción de censura y subsiguiente destitución de Alcalde deben quedar suspendidas hasta las primeras elecciones locales a celebrar después de la publicación de la Ley Orgánica 5/1985, de 19 de junio (R. 1463), "supone un serio menoscabo del libre pleno ejercicio del cargo público de Concejal, directamente elegido por los ciudadanos", tal como se declara en la sentencia de esta Sala de 15 de marzo de 1986 (R. 1090), en la que se aborda un supuesto idéntico al que ahora se enjuicia, llegándose a la conclusión de la procedencia de la tramitación de la proposición por la que se insta la celebración de un Pleno Extraordinario para tratar de una moción de censura de un Alcalde —el de Ceuta- y destitución del mismo. Esa misma doctrina ha sido también mantenida en la sentencia de 17 de marzo del mismo 1986 (R. 1091), en relación con la Alcaldía de Santiago de Compostela. (Sentencia de 15 de julio de 1986, Ar. 4360.)

\section{CONTRATACION ADMINISTRATIVA}

No PUEDE LA CORPORACIÓN MUNICIPAL DEJAR SIN EFECTO EL CONTRATO DE OBRAS PERFECCIONADO SI LA CAUSA PARA NO LLEGAR

A SER FORMALIZADO SE DEBE EXClUSIVAMENTE A LA ADMINISTRACIÓN MUNICIPAL: OBLIGACIÓN DE INDEMNIZAR 769.873 PESETAS

IMPORTE DEL BENEFICIO INDUSTRIAL DEJADO DE PERCIBIR POR EL CONTRATISTA ADJUDICATARIO

El representante de la Administración impugna la sentencia de instancia de 14 de junio de 1984, acatada por el recurrente en vía jurisdiccional Sr. C. P., basándose en que el contrato denunciado por el Excmo. Ayuntamiento de Tárrega mediante acuerdo de 4 de noviembre de 1982 no llegó a perfeccionarse y en que la resolución indemnizatoria acordada en la citada sentencia 
de instancia infringe la doctrina de esta Sala establecida en la sentencia de la misma fecha 3 de marzo de 1982; pero tales alegaciones no pueden tomarse en consideración, por cuanto respecto de la primera, debe tenerse en cuenta el precepto contenido en el artículo 45 del Reglamento de Contratación de las Corporaciones Locales (R. 1953, 1054 y N. Dicc. 22515), donde se establece que el contrato se perfeccionará por la adjudicación definitiva, concretando, además, que por ella los licitadores y la Corporación quedarán obligados a su cumplimiento; por otra parte, el artículo 48 del mismo texto reglamentario, aunque establece la obligatoriedad de la formalización escrita del contrato, señala también que la falta de este requisito no afectará a la validez de la obligación, facultándose a las partes para comp-lerse reciprocamente al cumplimiento de la citada formalidad $y$ aunque es cierto que el precepto autoriza a las Corporaciones contratantes a resolver el contrato mediante referencia expresa al artículo 65 del texto reglamentario, no lo es menos que tal circunstancia no se ha dado en el caso de autos pues si el acuerdo resolutorio de 4 de noviembre de 1982 llegó a adoptarse, no lo fue porque el Sr. C. P. mostrara resistencia a formalizar la escritura sino porque el mal planteamiento de la obra a realizar no permitia dar cumplimiento a lo pactado y la respon. sabilidad de ello recae exclusivamente sobre la Administración recurrente, como claramente se evidencia del informe técnico obrante al folio noveno del expediente; en definitiva, la falta de formalización de la escritura pública del contrato no priva de eficacia a la obligación contraída en el caso de autos, al no deberse ello a culpa, negligencia o resistencia del contratista, todo lo cual determina deba rechazarse este motivo de impugnación. (Sentencia de 19 de mayo de 1986, Ar. 4398.)

\section{IV́. FARMACIAS}

\section{NÚCLEO DE POBLACIÓN CONSTITUIDO POR VARIAS PARROQUIAS. CONCESIÓN DE LICENCIA PARA APERTURA DE FARMACIA}

El que las cinco parroquias del núcleo en cuestión no formen parte de un mismo Municipio, no es abstáculo por sí solo para la aplicación del precepto contenido en el citado artículo 3 del Real Decreto antes mencionado; como tampoco lo es -menos por supuesto- porque todo este núcleo de población no esté concentrado en un solo espacio, delimitado por un único perímetro, como lo viene reconociendo la jurisprudencia: Sentencias de 26 de septiembre de 1983 (R. 4534) y 17 y 22 de mayo de 1984 (R. 3141 y 3119).

CUARTo.-Estas circunstancias no deben erigirse en obstáculo para la consideracón de esta población dispersa en varias parroquias, como un núcleo de población idónea para que en su área se abra una nueva oficina de farmacia, debido a que entre ellas existe una cierta proximidad y vecindad y a que el alejamiento del mismo de las farmacias más próximas se mide, no por metros, sino por kilómetros.

QuINTo.-El motivo impulsor de nuestro razonamiento parte del principio 
inspirador del precepto en cuestión (el tan repetido artículo 3 del Real Decreto 909/1978), que no es otro que atender el interés público, que, en la población de que se trata, obligada a soportar el cúmulo de inconvenientes derivado de su dispersión $y$ de su distanciamiento de las cabezas de Municipio, se concreta en la conveniencia de que exista una oficina de farmacia dentro del propio núcleo disperso, con lo que se contribuye a mejorar las condicio nes de vida de esta población rural, y a lograr, en este aspecto concreto, la igualdad preconizada en el artículo 9.2 de nuestra Constitución (R. 1978, 2836).

SEXTA.-De otra parte, también hay que contar con que, en casos dudosos, la incertidumbre en esta materia se viene resolviendo en favor del principio "pro libertate», de acuerdo con una constante jurisprudencia; Sentencias de 12 de mayo, 13 de julio, 26 y 28 de septiembre, 5 de octubre, 13 de diciembre de 1983 (R. 2939, 4049, 4537, 5830 y 6795), 17 y 22 de mayo de 1984. (Sentencia de 23 de abril de 1986, Ar. 4369.)

\section{HACIENDAS LOCALES}

\section{IMPUESTO MUNICIPAL SOBRE LA PUBLICIDAD: NO ESTÁN SUJETOS LOS CARTELES SITUADOS EN LOS ESCAPARATES O DENTRO DEL ESTABLECIMIENTO}

El impuesto municipal sobre la publicidad tiene como hecho imponible la exteriorización mediante soportes gráficos de la existencia y cualidades de cosas o actividades, con la finalidad de atraer la atención de los eventuales consumidores o clientes y en tal sentido lo define el artículo 106 del Real Decreto 3250/1976, de 30 de diciembre, que contiene las normas para la aplicación de la Ley 41/1975, de 19 de noviembre, de Bases del Estatuto del Régimen Local. En consecuencia, el supuesto de hecho así configurado exige como componente intrínseco de la publicidad una circunstancia típica, la exhibición fuera del local propio, que desde un ángulo negativo recoge el artículo 109 del texto más arriba mencionado. No estará sujeta a este impuesto, dice literalmente, la exhibición de carteles situados en los escaparates o colocados en el interior de los establecimientos, cuando se refieran a los artículos o productos que en ellos se vendan. Por ello, es absolutamente correcta la exclusión en el presente caso de la propaganda mural dentro de los cines «Goya» y «Pacense», que anunciaba las representaciones teatrales o proyecciones cinematográficas a celebrar en ellos.

En esta misma línea de reflexiones, resulta conveniente recordar que el artículo 112 del Real Decreto 3250/1976 utiliza unos factores para obtener la deuda tributaria, uno el censo del Municipio, componente demográfico no discutido aquí y ahora, mientras el otro consiste en la superficie del rótulo o del cartel cuya exhibición constituye el hecho imponible. Pues bien, es razonable concluir que el concepto o fenómeno de la exteriorización gráfica gravite fundamentalmente sobre el mensaje o contenido y no sobre el soporte. A efectos del reclamo publicitario son aquéllos los importantes y no el volu- 
men o estructura, oculta o no, y en definitiva el bastidor donde se fija el anuncio verbal, gráfico o mixto. En consecuencia, si uno de los dos elementos manejados para determinar la tarifa o cuota es la extensión por metro cuadrado del rótulo o del cartel, no deben incluirse en el cómputo los marcos, molduras o elementos con una función exclusivamente ornamental o de apoyo físico, sin relación con el mensaje ni significado propio. En definitiva, ha de tomarse en cuenta la superficie útil y excluir cualquier otro elemento o componente ajeno. (Sentencia de 10 de julio de 1986, Ar. 4346.)

\section{IMPUESTO DE RADICACIÓN: SU CONTORNO LEGAL}

Constituye el hecho imponible del Impuesto de Radicación la utilización o disfrute, para fines industriales o comerciales, y para el ejercicio de actividades profesionales, de locales de cualquier naturaleza, sitos en el término municipal. Así, literalmente, lo configura el artículo 60 , párrafo $10^{\circ}$, del Real Decreto 3250/1976, de 30 de diciembre (R. 1977, 224 y N. Dicc. 25852 bis, nota), al igual que el artículo $10^{\circ}$ de la Ordenanza fiscal vigente para este arbitrio en el Municipio de Bilbao.

La expresión exacta de la tipificación del presupuesto de hecho de este tributo municipal, alude a la «utilización o disfrute», palabras cuyo significado ha de obtenerse por vía coloquial y desde una perspectiva más económica que jurídica. En efecto, se contempla este usufructo en sentido no técnico, vocablo que sintetiza el uso y aprovechamiento de las cosas, como comprensivo de sus dos modalidades, mediata e inmediata, indirecta o directa. Por tanto, resulta indiferente a tales efectos la distinción entre el uso común correspondiente a quien aparca su vehículo en el local (mediante precio, no se olvide) y el uso privativo predicable del aprovechamiento económico del local (y del servicio) que revierte al patrimonio del concesionario. (Sentencia de 29 de septiembre de 1986, Ar. 4657.)

\section{HUELGAS}

\section{SERVICIOS MÍNIMOS}

Concebida en la doctrina la huelga como la suspensión colectiva y concertada en la prestación de trabajo por iniciativa de los trabajadores, es un derecho recogido en el artículo 28.2 de la Constitución (R. 1978, 2836) cuando establece que «se reconoce el derecho a la huelga de los trabajadores para la defensa de sus intereses. La Ley que regule el ejercicio de este derecho establecerá las garantías precisas para asegurar el mantenimiento de los servicios esenciales de la Comunidad»; de donde se infiere que la huelga no es un derecho absoluto, en cuanto su ejercicio ilimitado podría impedir o dificultar el de otros derechos tan fundamentales, para evitar lo cual han de establecerse las garantías necesarias para asegurar el mantenimiento de 
los servicios esenciales de la Comunidad a que se refiere el precepto constitucional, limitaciones que han de entenderse, so pena de hacer el derecho ineficaz, con criterio restrictivo, con el fin, como reza el número 1.० del artículo 10 de la Constitución y recoge la Sentencia de esta Sala de 11 de julio de 1980 (R: 2950), de no imponer a las personas otras limitaciones en el ejercicio de sus derechos fundamentales, más que los que exijan el bien común y el respeto a los derechos de los demás interpretados de conformidad, como expresa el apartado $2^{\circ}$, con la Declaración Universal de Derechos Humanos y Tratados y Acuerdos Internacionales sobre las mismas materias ratificadas por España. (Sentencia de 22 de septiembre de 1986, Ar. 4640.)

\section{POLICIA MUNICIPAL}

\section{Licencia de obras. Denegación indebida. Responsabilidad DE LA CORPORACIÓN E INDEMNIZACIÓN DE DAÑOS Y PERJUICIOS}

Por lo que refiere a la indemnización de los daños y perjuicios ocasionados a la Cooperativa recurrente por la desestimación de su petición de licencia por el Ayuntamiento demandado solicitada por la apelante en ambas instancias, procede afirmar que en virtud de lo dispuesto en el artículo 106 de la Constitución: "Los particulares, en los términos establecidos en la Ley tendrán derecho a ser indemnizados, salvo en los casos de fuerza mayor, siempre que la lesión sea consecuencia del funcionamiento de los servicios públicos», con el que se hallan acordes el artículo 40 de la Ley de Régimen Jurídico del Estado por el que se declara ese derecho a la indemnización por el Estado de toda lesión que sufran los particulares, en sus bienes y derechos por el funcionamiento normal o anormal de los servicios públicos, los artículos 405 y 406-2. del Texto refundido de la Ley de Régimen Local y $37-1 .^{\circ}$ de su Reglamento de Organización, Funcionamiento y Régimen Jurídico y 121 de la Ley de Expropiación Forzosa y 122 de su Reglamento, por los que se determinan la responsabilidad directa de la Administración y de las Entidades Locales, en particular, por los daños producidos con ocasión del funcionamiento de los servicios públicos o del ejercicio de las atribuciones de la Entidad Local, sin culpa o negligencia grave imputables personalmente a sus Autoridades, Funcionarios y Agentes, procede hacer condena expresa del Ayutamiento demandado por la lesión sufrida en el patrimonio de la actora a consecuencia de la indebida denegación de la licencia, objeto de este Proceso, ya que existe prueba del nexo causal entre los daños y perjuicios inferidos a la recurrente $y$ el acto de la Corporación demandada de. clarado contrario a Derecho; responsabilidad directa de la Administración que exige según lo dispuesto en el artículo 405-2. de la Ley de Régimen Local el que el daño sea efectivo, material o individualizado; a cuyo efecto débese precisar que la inversión efectuada por la Cooperativa demandante para la adquisición de la parcela con la finalidad de construir en ella no puede ser 
objeto de indemnización, ya que no guarda relación con el rechazo de la licencia, en razón de que, en virtud de esta declaración jurisdiccional le será posible realizar la construcción, $y$, por contra, si debe ser indemnizada por el daño sufrido por causa de la denegación de la licencia, a partir del Acuerdo que rechazó la reposición contra el de 22 de junio de 1981, ya que el primer proyecto presentado como Anexo a una primera solicitud del permiso municipal, no fue conforme a Derecho, y si, como se ha expresado en los anteriores apartados, el modificado $y$ aportado con el recurso de reposición; daños consistentes en el coste financiero realizado para la compra de la parcela, o sea los intereses devengados desde la resolución del recurso de reposición el 26 de octubre de 1981 hasta la fecha en que se le dé la licencia, en cumplimiento de lo ordenado por esta resolución; indemnización que comprende también los perjuicios relativos y consecuentes al tiempo en que ha estado sin aprovechar la parcela a partir de la meritada resolución del recurso de reposición hasta le fecha en que pueda empezar la construcción; conforme todo ello con lo dispuesto en el artículo 42 y $84, c$ ), de la Ley Jurisdiccional quedando diferida al período de ejecución de Sentencia la determinación de la cuantía de los mismos, conforme a las bases citadas: responsabilidad objetiva deducible por la declaración de nulidad de un acto de la Administración, que por sí sola no presupone el derecho a la indemnización según el artículo 40 de la Ley de Régimen Jurídico del Estado; pues el reconocimiento de ese derecho exige que se pruebe la existencia efectiva de unos daños y perjuicios y la relación de causa a efecto entre éstos y el acto anulado por resolución judicial, lo que ha sido probado en este proceso por lo que débese dar lugar en esta sentencia a la indemnización pedida por la recurrente con la limitación referida; doctrina acorde con reiterada Jurisprudencia de este Tribunal Supremo, Sentencias de 2-12-72 (R. 5269), 17-5-75 (R. 3249), 13-6-75 (R. 3468), 3-5-77 (R. 2683) y 9-2-83 (R. 816), entre otras, respecto a la responsabilidad objetiva de la Administración, y el derecho a obtener justa reparación por los daños y perjuicios ocasionados a los intereses y derechos patrimoniales de los administrados por los actos declarados contrarios a Derecho por la Jurisdicción Contencioso-Administrativa. (Sentencia de 29 de abril de 1986, Ar. 4380.)

\section{NO PUEDE CONSIDERARSE COMO LICENCIA DE OBRAS LO QUE NO ES OTRA COSA QUE MERO INFORME MUNICIPAL A CONSULTA URBANÍSTICA. INDEMNIZACIÓN PROCEDENTE}

La petición principal de la demanda no puede prosperar, porque el acuerdo de la Comisión Municipal Permanente de 4 de abril de 1978 que resolvió la petición del actor de que se le señalare línea, rasante y volumen en Estribela no concede una licencia de construcción sino que es un informe a una mera consulta urbanística, regulada en el artículo 55-2 de la Ley del Suelo, que no vincula al órgano municipal, ni puede configurarse como un acto administrativo propio de los que se derivan situaciones juridicas o derechos subjetivos que no puedan desconocerse, sin perjuicio de indem- 
nizar los costes del proyecto y demás gastos que procedieren si la licencia que posteriormente se pretendiese a tenor de la información se denegase -Sentencias de 29 de septiembre y 20 de febrero de 1980 (R. 3459 y 1724) y 5 de abril de 1982 (R. 2378) -; ni le corresponden mayores alturas según el Plan General (expediente, folio 32). (Sentencia de 8 de mayo de 1986, Ar. 4393.)

\section{NO PRECISA LA LICENCIA MUNICIPAL LA CONSTRUCCIÓN DE UNA AUTOPISTA}

En cuanto al fondo del asunto, el Ilmo. Ayuntamiento recurrente parte de una interpretación literal de los artículos 178 y siguientes de la Ley de Régimen del Suelo y de sus concordantes del Reglamento de Disciplina urbanística (R. 1978, 1986), sin consideración alguna a los planteamientos implícitos de la Ley que la sentencia de instancia, en su tercer considerando. señala, al distinguir entre ordenación del territorio y urbanismo estricto, particular no nítidamente distinguido en los textos legales y reglamentarios, pero ya acogido por la doctrina jurisprudencial, como se infiere de una serie de sentencias de esta Sala, de las que es paradigma, por su específica formulación, la de 30 de marzo de 1984 (R. 2541).

A la vista de lo expuesto y de la naturaleza de la obra a ejecutar, es obvio que la realización de las obras de construcción de la autopista de Campomanes (Asturias) a León, no puede calificarse de actividad puramente urbanistica, en el sentido estricto de este término, sino de gran obra a realizar por la Administración del Estado, por lo que no es necesaria la autori. zación o licencia de obras del Ayuntamiento de Lena, pues basta para ello con la aprobación del proyecto realizado por el Ministerio de Obras Públicas. (Sentencia de 28 de mayo de 1986, Ar. 4471.)

\section{RUINA: CONCEPTO DE LA RUINA TÉCNICA: EVOLUCIÓN DE LA DOCTRINA DEL TS}

CONSIDERANDO: Que no cabe encajar el supuesto enjuiciado en ninguno de los apartados del artículo 183 de la Ley sobre Régimen del Suelo y Ordenación Urbana referentes a la ruina técnica, a la ruina económica y urbanistica, puesto que ni el coste de las reparaciones ni el valor de las mismas en relación con el del edificio encajan en dicho precepto ateniéndonos a los informes periciales referidos. Porque no existe posibilidad de tipificar los daños en el supuesto a) de la misma norma que supone la declaración de estado ruinoso cuando los daños en cuestión no sean reparables técnicamente por los medios normales. $\mathrm{Y}$, a este respecto, conviene precisar que la doctrina tradicional de nuestra jurisprudencia estimaba que era daño no reparable aquel que exigía obras de consolidación de elementos estructurales o reconstrucción de éstos mediante previa demolición -Sentencias a este respecto del Tribunal Supremo de 29 de octubre de 1975, 16 de enero 
de 1967, 13 de noviembre de 1979, etc.- Sin embargo la sentencia del mismo Alto Tribunal de 16 de noviembre de.1982, reiterando un camino ya trazado en otras anteriores, establece a propósito de la llamada ruina técnica, que no toda consolidación o reconstrucción de elementos estructurales o básicos del edificio constituyen el supuesto de ruina contemplado en el artículo 183.1, a), del Texto Refundido de la Ley del Suelo de 9 de abril de 1976. En la misma se declara que las técnicas constructivas permiten hoy concep. tuar de normas supuestos de obras llamadas de consolidación de cimientos, estructuras y saneamientos que sean de poca importancia cuantitativa o cualitativa; señala como limite conceptual de dicha doctrina el alto coste de la reparación o el real agotamiento generalizado del edificio. En virtud de ello será daño de reparación normal aquel que, aunque suponiendo obra de reconstrucción que afecte a algún elemento estructural, sea de alcance parcial, de coste no excesivo y se realice en edificio en buen estado genergl de conservación sin sintomas de agotamiento estructural. (Sentencia de 1 de abril de 1986, Ar. 4206.)

\section{RUINA: VALOR DE LOS INFORMES TÉCNICOS}

Considerando que en los procesos declaratorios de ruina el Tribunal debe acomodar su decisión a los criterios técnicos aportados al expediente administrativo o a los producidos en esta vía jurisdiccional, ponderando y contrastando los distintos dictámenes relativos a los daños que hayan de repararse, coste de la reparación y valor del edificio, datos éstos sustancialmente técnicos y con frecuencia de valoración dispar, por lo que la jurisprudencia se ha pronunciado en el sentido de reconocer un valor superior a los informes de los técnicos municipales; porque éstos son, más que unos peritos ajenos al circulo municipal, órganos municipales a los que incumbe la asistencia técnica del llamado a decidir, alejados en principio de los privados intereses en pugna y por lo tanto más objetivos. (Sentencia de 1 de abril de 1986, Ar. 4206.)

\section{PROCEDIMIENTO ADMINISTRATIVO}

\section{NOTIFICACIONES: POR CORREO CERTIFICADO: ENTREGA A PERSONA DISTINTA DEL DESTINATARIO}

El artículo 80-2 de la Ley de Procedimiento Administrativo lo que dice es que el receptor puede ser persona distinta del destinatario cuando éste no se hallare en el domicilio, y que en tal caso debe -el receptor- hacer constar su parentesco con el destinatario o la razón de su permanencia en el domicilio. Lo que no dice la Ley es la forma o manera en que tal declaración debe quedar reflejada documentalmente a efectos de prueba. Esto último lo dice la Orden del Ministerio de la Gobernación de 20 de octubre 
de 1958 (R. 1691 y N. Dicc 24710) sobre aplicación por el Servicio de Correos de los artículos 66 y 80 de la Ley de Procedimiento Administrativo. En esta norma reglamentaria se dice, en efecto, que «de no hacerse la entrega al propio destinatario se hará constar en la libreta de entrega la condición del firmante que reciba el objeton. Puede quizá ser deseable que en un futuro la norma reglamentaria $\longrightarrow$ incluso, tal vez, la misma Ley- prevea que la consignación del nombre y condición del receptor se haga en la tarjeta rosada que hoy se utiliza como acuse de recibo. Pero, actualmente, el reflejo documental de ese dato debe constar sólo en la libreta de entrega (lo que no impide que se pueda hacer constar también en dicha tarjeta). De manera que la notificación estará bien hecha con que se cumpla lo que la norma dice. (Sentencia de 9 de mayo de 1986, Ar. 4395.)

\section{RESPONSABILIDAD DE LA ADMINISTRACION}

Se estima que es responsable el Ayuntamiento y SE le condena

A INDEMNIZAR A UNA EMPRESA INDUSTRIAL LA CANTIDAD

DE 34.925.991 PESETAS POR LOS DAÑOS Y PERJUICIOS

QUE SE LE ORIGINARON A AQUÉLla A CONSECUENCIA DEL AGUA

DE LLUVIA QUE ANEGÓ LA FÁBRICA POR HALLARSE

OBSTRUIDA LA REJILLA DEL COLECTOR DE AGUAS PLUVIALES

SEgundo: Que, la responsabilidad patrimonial de la Administración, según se desprende de la doctrina jurisprudencial, queda configurada mediante el acreditamiento de una serie de requisitos, tales como: a) efectiva realidad del daño, evaluable económicamente $e$ individualizado en relación a una persona o a un grupo de personas, b) que el daño o lesión patrimonial sufrido por el reclamante sea consecuencia del funcionamiento normal o anormal de los servicios públicos en una relación directa, inmediata y exclusiva de causa a efecto, sin intervención extraña que pudiera influir alterando, el nexo causal, $y$ c) que no se haya producido fuerza mayor (Sentencias de 2 de febrero de 1980, R. A. 743, 4 de marzo de 1981, R. A. 894 y 25 de junio de 1982 , R. A. 4.852 ).

Tercero: Que desde un punto de vista normativo, la posibilidad teórica de exigir responsabilidades a la Administración local por el funcionamiento de los servicios públicos viene reconocida en el artículo 106.2 de la Constitución española, punto culminante de una evolución que se inició en el artículo 121 de la Ley de Expropiación Forzosa confirmándose en el artículo 40 de la Ley de Régimen Jurídico de la Administración del Estado, disposiciones que, pese a referirse a otra «Administración», son plenamente aplicables al ámbito local como ha reconocido entre otras, la Sentencia de 8 de julio de 1982 (R. A. 5376).

Cuarto: Que, en el presente supuesto, la Administración, justifica su exención de responsabilidad en los daños causados, en base a la excepcional 
intensidad de las aguas caídas en Madrid los días 10 y 11 de febrero de 1979. apreciación que, no puede ser compartida, pues, los indices de 9,8 y 16 litros por metro cuadrado apreciados por el Instituto de Metereologia, no merecen la calificación de excepcionales por lo que en modo alguno pueden ser constitutivos de una situación de fuerza mayor, única hipótesis excepcionante de la responsabilidad de la Administración, y que viene siendo definida por la jurisprudencia como: "aquellos hechos que, aun siendo previsibles, sean sin embargo, inevitables, insuperables e irresistibles, siempre que la causa que los motive sea extraña $e$ independiente a la voluntad del sujeto obligado"s.

Quinto: Que los daños se han producido por una deficiente conservación del cauce del Arroyo Bueno y por una solución técnica no del todo satisfactoria para evitar la acumulación de residuos en la boca del colector, omisiones que, son imputables a la Administración demandada, la cual, entre sus atribuciones, cuenta con potestades específicas para impedir o en su caso sancionar el abandono de objetos en el citado cauce que, constituye un bien de dominio público municipal afecto a la prestación de un servicio público y sujeto por tanto a un régimen jurídico especial de defensa y protección como se desprende de los articulos 183 y 184 de la Ley de Régimen Local; en tales circunstancias, los daños se produjeron como consecuencia del funcionamiento anormal de un servicio público y por tanto indemnizables por la Corporación Local demandada (Sentencia del T. S. de 26 de octubre de 1983, R. A. 5978); razones de justicia aconsejan que los daños causados a los par. ticulares o administrados por el funcionamiento de los servicios puolicos que benefician a toda la colectividad no deben ser soportados individualmente por los afectados, sino por todos los ciudadanos a través de la propia Administración. (Sentencia de 8 de julio de 1982, Ar. 5376.) (Sentencia de 23 de mayo de 1986, Ar. 4455.)

\section{SERVICIOS PUBLICOS}

\section{PRESTACIÓN POR LAS AUTORIDADES MUNICIPALES: OBRAS DE ADAPTACIÓN} DE LA VIA PÚBLICA A LOS DISMINUIDOS FÍsICOS

A la misma conclusión hay que llegar si se trae a colación el artículo 49 de la vigente Constitución española, conforme al cual «los poderes públicos realizarán una política de previsión, tratamiento e integración de los disminuidos físicos; sensoriales y psíquicos, a los que prestarán la atención especializada que requieran y los ampararán especialmente para el disfrute de los derechos que este título otorga a todos los ciudadanos», derechos entre los que se encuentra, por ejemplo, el de circulación (art. 19), debiendo recordarse que este mandato del artículo 49, pese a estar incluido bajo la rúbrica «de los principios rectores de la política social y económica», no es una mera norma programática, que limite su eficacia al campo de la retórica política o de la estéril semántica de una declaración demagógica. Porque como ya precisó hace años el Tribunal Supremo norteamericano, en el caso Trop versus 
Duller, alas declaraciones de la Constitución no son adagios gastados por el tiempo; ni una contraseña vacía de sentido. Son principios vitales, vivos, que otorgan y limitan los poderes del Gobierno de nuestra Nación. Son regulaciones de Gobierno». Y esta doctrina, aunque establecida por un Tribunal extranjero con referencia a la Constitución de su país es perfectamente trasladable a nuestro ámbito para subrayar el sentido de los artículos 9,1 y número 3 de la Disposición derogatoria de la Constitución española. De manera que ese artículo 49 , como los demás de esa misma rúbrica, como la totalidad de los que integran la Constitución, tienen valor normativo y vinculan a los poderes públicos, cada uno en su respectiva esfera, a hacerlos eficazmente operativos.

En el mismo sentido debe añadirse que el Código Civil dice que las normas se interpretarán según «la realidad social del tiempo en que han de ser aplicadas", y es patente que la que nos ocupa desenvuelve su vigencia en el marco de un Estado social de Derecho diseñado por una Constitución de aplicación inmediata y directa (art. 9,1 y Disposición derogatoria 3). De aquí que la reciente Ley básica estatal de Régimen Local de 2 de abril de 1985 (R. 799 y 1372) establezca en su artículo 18,1 letra g, el derecho de los vecinos a aexigir la prestación $y$, en su caso, el establecimiento del corres. pondiente servicio público, en el supuesto de constituir una competencia municipal propia de carácter obligatorio». (Sentencia de 9 de mayo de 1986, Ar. 4395.)

\section{URBANISMO}

\section{Ambito de competencia de los Delegados Provinciales DEL MOPU}

CONSIDERANDO: Que se impugna en el presente recurso la resolución de la Delegación Provincial de Toledo del Ministerio de Obras Públicas y Urbanismo de fecha 27 de junio de 1979 (confirmada presuntamente en alzada) por la cual se resolvió conceder a D. Gonzalo M. C. y a D. Fernando M. de L., primero, un nuevo plazo de un mes para subsanar las deficiencias relativas a la red de distribución y caudal de agua, transcurrido el cual se procederá de acuerdo con el artículo 61 del Reglamento de Disciplina Urbanística y, segundo, conceder nuevo plazo de tres meses para subsanar el resto de las deficiencias recogidas en la Resolución del Consejo de Ministros de fecha 15 de octubre de 1977, todo ello con referencia a la Urbanización «Los Pradillos" de Illescas y Yeles (Toledo).

CoNSIDERANDO: Que en cambio, debe ser estimado el segundo motivo de impugnación que se esgrime, a saber, la incompetencia del Delegado Provincial del Ministerio de Obras Públicas y Urbanismo de Toledo para dictar el acto que aqui se recurre. $Y$ es que, en efecto, las Delegaciones Provinciales del Ministerio no están mencionadas en el artículo 207 del Texto refundido de la Ley del Suelo de 9 de abril de 1976 (R. 1192 y N. Dicc. 30298) entre los 
órganos centrales y locales a quienes tal Ley concede competencia para el desarrollo de las actividades reguladas en la misma, sino que los órganos periféricos de la Administración Central que tienen tal competencia son las Comisiones Provinciales de Urbanismo de las cuales los Delegados Provinciales son unicamente los Vicepresidentes -art. I del Decreto 2682/78, de 1 de septiembre (R. 2465)-, y entre sus funciones -que siguen siendo las reguladas en la Orden de 27 de enero de 1973 (R. 162 y N. Dicc. 8686)-, no se encuentran, en materia de urbanismo, según el artículo 18 de la misma, ninguna que haga referencia a competencias resolutorias, sino, unicamente, las que se refieren a la tutela, fomento, vigilancia y control de la actividad urbanistica en el territorio de la respectiva Provincia, por cuya razón se ha podido decir que tales Delegaciones Provinciales son sólo órganos de preparación y ejecución de los acuerdos que corresponden a la citada Comisión Provincial, a diferencia de lo que ocurre en otros aspectos, (V. G. en materia de vivienda, según el artículo 17 de la citada Orden) en que, en efecto, tienen competencias más amplias, competencia de las Comisiones Provinciales de Urbanismo que afirma sin perjuicio, desde luego, de la que pueda corresponder a los Ayuntamientos y a las Diputaciones, como auténticos órganos de carácter local -art. 207-2-b) y c) del mencionado Texto refundido-, de forma que el acto recurrido ha sido dictado por órgano competente (ello sin contar con que para la imposición de las obras de urbanización a que se refiere el acto recurrido debe principiarse por exigir la formulación del correspondiente proyecto de urbanización, cuya falta también quedó acreditada en el expediente sancionador, necesario para llevar a la práctica los planes parciales, según el artículo 11 de la vieja Ley de 1956 (R. 773, 867 y N. Dicc. 30144) y el artículo 15-1 del actual Texto refundido), y tal incompetencia en el órgano autor del acto recurrido debe llevar necesariamente a la estimación del recurso, según ló dispuesto en el artículo 48-1 de la Ley de Procedimiento Administrativo (R. 1958, 1258, 1469, 1504; R. 1959, 585 y N. Dicc. 24708). (Sentencia de 4 de abril de 1986, Ar. 4362.)

\section{Construcción en SUelo URBanizable, PROGRamado, previa aprobación del Plan Parcial y Proyecto de Urbanización}

Analizando el tema relativo a la legalidad de la licencia impugnada, es de ver que ninguno de los alegatos de la parte tiene virtualidad suficiente para lograr el propósito anulatorio perseguido, y ello por lo siguiente: $10^{\circ}$, el artículo 42.2 del Reglamento de Gestión Urbanistica permite la edificación en suelo urbanizable programado, previa aprobación del Plan Parcial y Proyecto de Urbanización, incluso antes de que los terrenos estén totalmente urbanizados, siempre que se cumplan los requisitos señalados en el artículo $41, y$ con los efectos expresados en el mismo, es decir, en esencia, que sea firme en via administrativa el acto de aprobación del proyecto de reparcelación o de compensación si uno $y$ otro fueren necesarios para la distribución de los beneficios y cargas del Plan, que por el estado de las cosas sea previsible que a la terminación de la edificación «la parcela» de que se trate 
contará con todos los servicios necesarios para tener la consideración de solar, compromiso relativo a no utilización de la construcción hasta que no esté concluida la obra de urbanización, estableciendo tal condición en las cesiones que se lleven a efecto, $y$ todo ello sin que se permita la ocupación de los edificios hasta que no esté realizada totalmente la urbanización que afecte a los mismos, con la precisión de que el incumplimiento del deber de urbanizar simultáneo a la edificación, comportará la caducidad de la licencia; $2 .^{\circ}$, de lo anterior se infiere que carece de relevancia el alegato de que el terreno no tiene la condición de solar, pues en el caso que nos ocupa ha de partirse, precisamente, de que al solicitarse la licencia no ostentaba tal carácter, como demuestra el primer informe del Arquitecto Municipal, emitido en 11 de febrero de 1982, tras la petición de la licencia, al aludir a los artículos 41 y 42 del Reglamento de Gestión, que, específicamente, según dicho informe, basan el dictamen favorable a la concesión, pues, además, como se expresa en el mismo y se constata en autos, el Plan Parcial ya antes aludido, estaba en vigor y existía aprobado un Proyecto de Urbanización, presupuestos básicos, según el citado articulo 42.2 para la posibilidad de edificar en suelo urbanizable programado. (Sentencia de 26 de mayo de 1986, Ar. 4457.)

\section{Estudios de Detalle}

Se estima procedente la aprobación municipal de un Estudio de Detalle, solicitada al efecto, cuando dicho Estudio está dentro de sus propios límites y se acomoda a las normas del Plan General de Urbanismo, aun cuando falte el Plan Parcial.

Es interesante la consideración del Tribunal respecto del aserto que hace el Ayuntamiento de que no puede clasificarse el terreno donde el particular trata de edificar de suelo urbano porque no tiene el servicio de suministro de energía eléctrica, diciendo al efecto el Tribunal: «Se llega a la conclusión de que ese servicio existe, pues como pone de relieve el dicta. men emitido por el Ingeniero de Caminos Sr. P. F. en el periodo probatorio, no se puede hacer depender la concesión de una licencia edificatoria de la existencia de una línea o transformador en la propia parcela en que se pretende construir, sino que lo que debe tomarse en cuenta es si se puede o no dar suministro, ya que como en el mismo informe se razona es práctica inusual en las compañías suministradoras de energía eléctrica el tener líneas de suministro en parcelas sin edificar, pues ello representaría un gasto sin ingresos por consumo que compensara aquél, es decir, lo que debe exigirse, como indica el mencionado artículo segundo del Real Decreto-ley 16/1981, es que esos servicios tengan las características adecuadas para servir a la edificación que se haya de construir, que es lo que ocurre en el presente caso, donde existe un centro de transformación de $400 \mathrm{KV}$ a cincuenta metros de distancia y siendo así, los terrenos afectados por el Estudio de Detalle deben considerarse suelo urbano por contar con los cuatro servicios que han quedado citados. (Sentencia de 2 de abril de 1986, Ar. 2220.) 


\section{ORDEN MUNICIPAL IMPONIENDO EL DERRIBO DE OBRAS EJECUTADAS SIN LICENCIA Y QUE CONTRAVIENEN LA NORMATIVA URBANÍSTICA}

Y tampoco es atendible la pretensión de alzamiento de la orden de derribo contenida en el acto sancionador objeto de revisión jurisdiccional, por cuanto, aunque es cierta la doctrina de esta Sala alegada, concretamente expuesta en la Sentencia de 23 de noviembre de 1981 debe tenerse en cuenta que ella se halla orientada a evitar el derribo de aquellas obras realizadas sin licencia o quebrantamiento o de los límites de la concedida pero que son legalizables con arreglo al planeamiento o normas urbanísticas aplicables, caso que no se da en el de autos, por cuanto solicitada por el recurrente la licencia legalizadora de las obras en curso en 1979, ella fue denegada por no ser factible tal legalización. (Sentencia de 2 de abril de 1986, Ar. 4218.)

\section{SUELO URBANO Y NO URBANIZABLE}

No puede concederse licencia de edificación cuando no se tiene aprobado el Plan General de Ordenación Urbana ni el Proyecto de delimitación del suelo urbano, y el terreno donde se trata de construir no es terreno urbano.

Considerando: Que partiendo del hecho indubitado de que el Ayuntamiento de San Pedro del Pinatar carece de Plan General de Ordenación Urbana, definitivamente aprobado, o de cualquier otra norma propia de planeamiento, lo que limita la clasificación de su suelo en urbano y no urbanizable, se ha de determinar, ante todo, si el lugar donde se construye y para el que ha sido otorgada la licencia impugnada tiene o no la calificación de suelo urbano; para lo que hay que partir de que sólo obtienen este carácter los terrenos que cuenten con acceso rodado, abastecimiento y evacuación de agua y suministro de energía eléctrica o alternativamente estén comprendidos en áreas consolidadas por la edificación, al menos, en la mitad de su superficie; criterios materiales que se completan -en uno y otro caso-con un segundo requisito formal, que exige su inclusión en un proyecto de delimitación del suelo urbano, tramitado por el Ayuntamiento en forma análoga a la de los Planes (artículo 81 del Texto refundido de la Ley del Suelo); proyecto de delimitación del suelo urbano que no es un auténtico Plan, es decir, un auténtico instrumento de ordenación, sino, pura y simplemente, un medio a través del cual se constata, aplicando los criterios obligatorios que da el Texto refundido, qué suelo dentro de un término municipal es suelo urbano, y qué suelo, por pura exclusión, es suelo no urbanizable, y todo ello no para ordenar suelos como a bien tenga la Administración, sino para aplicarles automáticamente la ordenación directa, obligatoria y exacta que, a falta de planeamiento, contiene el citado Texto refundido (artículos 72, 73 y 74 para el suelo urbano y el artículo 86-1 en relación con el 85 para el suelo no urbanizable); sin embargo, como el Ayuntamiento de San Pedro del Pinatar no tiene aprobado definitivamente el proyecto de delimitación del suelo, y que venía obligado a ejecutar en el plazo de un año desde la entrada 
en vigor de la Ley 19/1975 (R. 918 y N. Dicc. 30144) de modificación de la primitiva Ley del Suelo -disposición transitoria 5.:-3-, sin que tampoco la Comisión Provincial de Urbanismo, Estatal o Autónoma, se haya subrogado en el cumplimiento de tal obligación legal, la única conclusión a que puede llegarse, si no se quiere impedir cualquier edificación en el Municipio, es la de dar realidad a las situaciones de hecho ya consolidadas en el Municipio $y$ partir de ellas para realizar la clasificación del suelo. (Sentencia de 3 de abril de 1986, Ar. 4362.)

\section{SOLAR: DELIMITACIÓN DEL CONCEPTO DE SOLAR}

En cuanto al tema debatido entre las partes procesales sobre la consideración legal de solar del terreno en que la recurrente pretende edificar, procede tener en cuenta que aun cuando la finca carece de algunos de los elementos tipificadores de solar, según los preceptos comprendidos en los artículos 78, a), 81.2 y 83.1 del Texto refundido de la Ley del Suelo, como los relativos a pavimentación y alcantarillado, y dispone de otros como el de alumbrado público, es lo cierto que el propio recurrente durante la tramitación del expediente de gestión -folio $24-$, de conformidad con la norma citada en último lugar, ofreció asegurar la ejecución simultánea de la urbanización y la edificación, comprometiéndose a otorgar las garantías proporcionales que el Ayuntamiento estimase oportuno, dando cumplimiento, por tanto, a la previsión establecida en el artículo 83.1 del Texto refundido antes mencionado, de donde se concluye que la exigencia de la calidad de solar en el terreno mencionado ha sido satisfecha. (Sentencia de 30 de mayo de 1986, Ar. 4477.)

NEMEsio RODRf́́guez MORO 
REALA-1987, núm. 233. BOIX REIG, VICENTE. PROBLEMAS ACTUALES DE LA CONTRATACION LOCAL.

REALA-1987, núm. 233. BOIX REIG, VICENTE. PROBLEMAS ACTUALES DE LA CONTRATACION LOCAL. 